\title{
MOLECULAR EVOLUTION \\ AND \\ THE FOSSIL RECORD
}
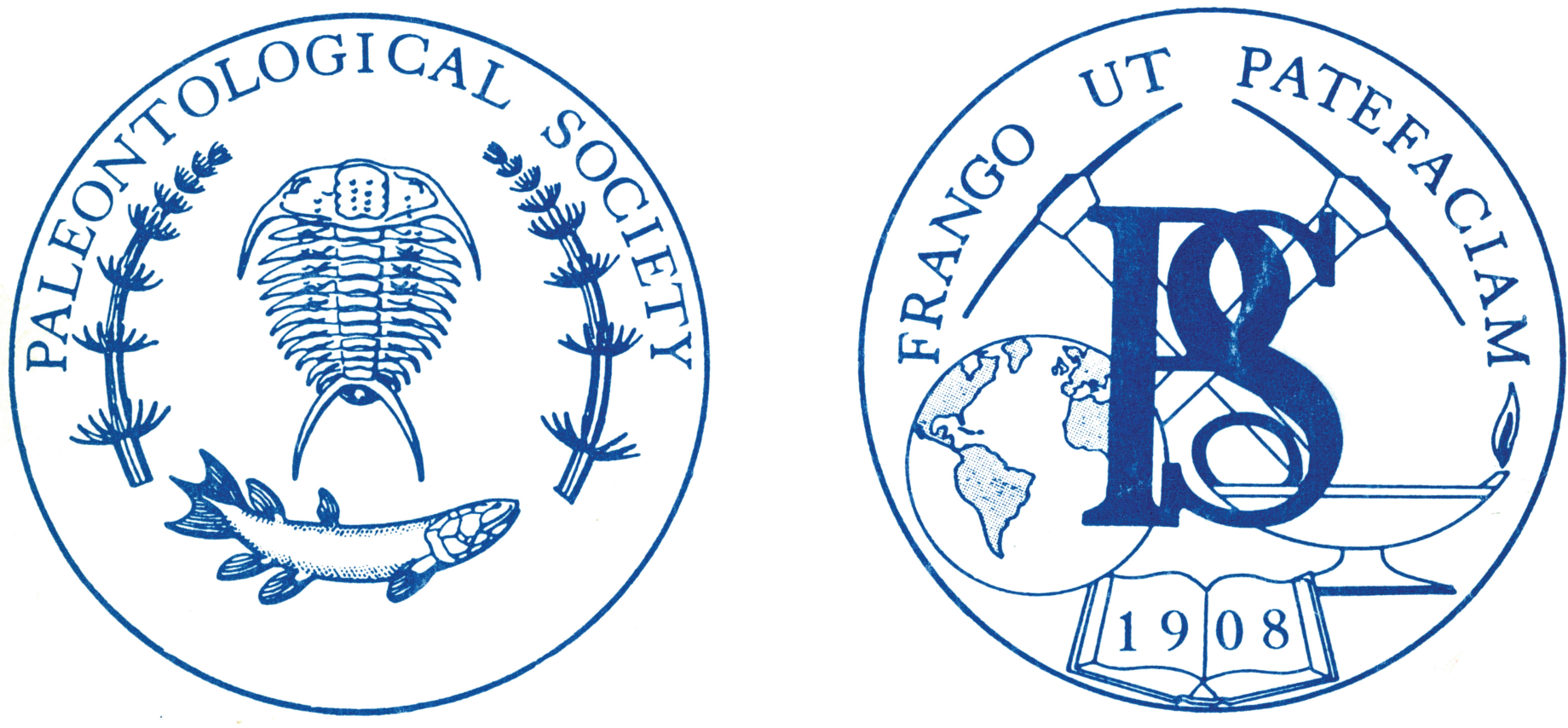

\section{SHORT COURSES IN PALEONTOLOGY}

NUMBER 1

1988

convened by Bruce Runnegar and J. William Schopf

Thomas W. Broadhead, Series Editor

A Publication of The Paleontological Society 


\section{MOLECULAR EVOLUTION AND \\ THE FOSSIL RECORD}
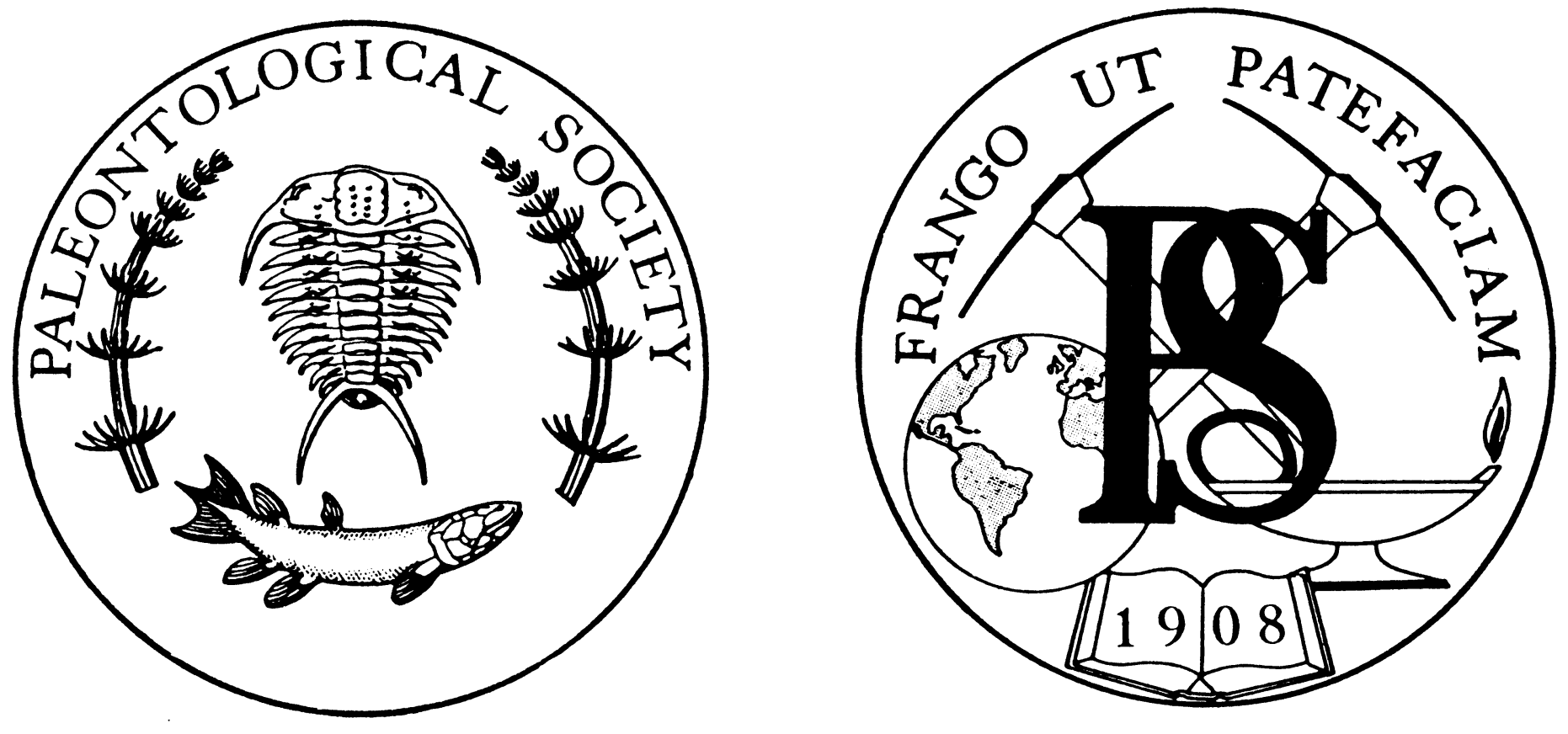

\section{SHORT COURSES IN PALEONTOLOGY \\ NUMBER 1}

1988

convened by Bruce Runnegar and J. William Schopf

Thomas W. Broadhead, Series Editor

A Publication of The Paleontological Society 
Program. . . . . . . . . . . . . . . . . . . . . . . . . . ii

Preface. . . . . . . . . . . . . . . . . . . . . . . . . . . . .

Speakers . . . . . . . . . . . . . . . . . . . . . . . . . . . . . iv

Introduction to the Short Course and to Basic Biochemistry . . . . . . . . . 1 by Bruce Runnegar

Immunological Methods for Determining Phylogenetic Relationships . . . . 12 by Jerold M. Lowenstein

Amino Acids and Proteins from Fossils. . . . . . . . . . . . . . . . . 20 by Gordon B. Curry

The Use of Amino Acid Sequences in Phylogenetic Analysis . . . . . . . . . 34 by K.A. Joysey

Molecular Time Scale for Evolution . . . . . . . . . . . . . . . . . 49 by Allan C. Wilson, Howard Ochman and Ellen M. Prager

Ribosomal RNA Sequences and the Early History of the Metazoa . . . . . . 63 by Rudolf A. Raff

DNA-DNA Hybridization, Phylogenetic Reconstruction and the Fossil Record . 75 by Charles R. Marshall

Precambrian Biochemical Evolution. . . . . . . . . . . . . . . . . 89 by J. William Schopf

Biomarkers: Molecular Fossils. . . . . . . . . . . . . . . . . . 98 by Roger E. Summons

Biochemical Innovations, Oxygen and Earth History. . . . . . . . . . . . .114 by Kenneth M. Towe

The Role of Macromolecules in the Formation of Mineralized Skeletons • • .130 by Stephen Weiner

Biochemical Evolution and the History of Life. . . . . . . . . . . . . . .138 by W. Ford Doolittle

References . . . . . . . . . . . . . . . . . . . 146 